\title{
Understanding and managing the Westerschelde - synchronizing the physical system and the management system of a complex estuary
}

\author{
A. van Buuren, L. Gerrits, and G. R. Teisman \\ Erasmus University Rotterdam, Department of Public Administration, P.O. Box 1738, 3000 DR Rotterdam, The Netherlands
}

Received: 9 May 2008 - Published in Hydrol. Earth Syst. Sci. Discuss.: 11 June 2008

Revised: 25 October 2010 - Accepted: 6 November 2010 - Published: 16 November 2010

\begin{abstract}
This article analyzes the relationship between the processes of policy making, management and research and the way in which the Westerschelde estuary developed between 1985 and 2006. The Westerschelde has three core functions: economically: it makes the port of Antwerp accessible; ecologically: it generates habitats for certain unique species; and in terms of safety: its morphology helps preventing the hinterland from being flooded. We analyze how the processes of policymaking, management and analysis focused on these three aspects, and how they in turn affected the physical system of the Westerschelde.

We proceed to develop a framework for evaluating the policy making, management and esearch and how this impacts the Westerschelde. We apply this framework to twenty years of policy making on, management of, and research about the Westerschelde. We conclude that policy, management and research, due to learning effects, take the dynamics of the Westerschelde into account to a greater extent than they have in the past, but there exist a real probability for old routines to return.
\end{abstract}

\section{Introduction}

The Westerschelde estuary stretches from the city of Antwerp in Flanders (Belgium) through the Dutch province of Zeeland and discharges in the North Sea. As an estuary it has three main functions for its societal environment. Firstly, it is the only maritime access from the sea to the port of Antwerp. Secondly, it is an important ecological subsystem within the delta system of the North Sea. Thirdly, it has a flood protection role because its morphology dissipates the tidal energy. Contrary to other sea arms in the Dutch delta,

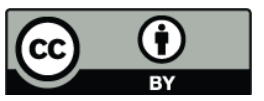

Correspondence to: L. Gerrits (gerrits@fsw.eur.nl) which were closed by sluices and dams during the Deltawerken policy program following the 1953 flood, the Westerschelde remained open due to its economic importance for the port of Antwerp.

The Westerschelde does have various other functions, especially with regard to fisheries and recreation. Additionally, its river banks have an important function in accommodating agriculture and other spatial functions such as housing. However, in the remainder of this article we focus on the three core functions of the estuary as summarized above especially because these are the three functions as mentioned in the main policy documents (LTV, 2001; ProSes, 2005) which are leading in the debate on the future of the estuary. In the conclusions of our paper we reflect on the limitations of this choice.

These three functions are as important as they are difficult to integrate. Good accessibility to the port requires deeper channels and frequent dredging of the ever-silting thresholds in these channels. However, these activities have two negative side-effects: the ecological value of the Westerschelde is considered lowered, and the velocity of its currents and the volume of water increases, which is considered dangerous. Regardless, in the late 1990s the governments of the Netherlands and Belgium have agreed to integrate the three functions in the development of this physical system.

The tensions between these functions make the Westerschelde a subject of fierce policy debates between actor coalitions favouring one of them. The port authorities of Antwerp in cooperation with a powerful Flemish politicaladministrative coalition are constantly seeking to improve the access to the port through the Westerschelde. They need permission from Dutch authorities as the Westerschelde is located on Dutch territory. The Dutch authorities and stakeholders however, are more focused on the other two functions. The ongoing policy debate between the Flemish and Dutch government about the Westerschelde make for an interesting case to study, as it is during that debate that the

Published by Copernicus Publications on behalf of the European Geosciences Union. 
different demands are articulated, defined and refined. This policy debate has been going on since the 1960's and has been well-documented in various Ph.D. theses (cf. Meijerink, 1998; Van Buuren, 2006; Gerrits 2008) and other sources (Gerrits et al., 2009; Van Buuren, 2009; Warner and Van Buuren, 2009).

Fulfilling these three demands largely depends on the systemic characteristics of the Westerschelde. Knowledge about the development of the physical system is therefore essential for policy making as well as for managing the morphology of the physical system. The physical system does have an autonomous logic but also responds to social action and determines, to a large degree, the way in which policy makers can feasibly integrate the three objectives of accessibility, ecological preservation and safety (Gerrits, 2008).

This article focuses on the interrelation between the social system and the physical system and sheds light upon the way in which synchronization between the physical system characteristics and the ensuing demands on the social system evolved over the last two decades. We are especially interested in the way the management, policy and research systems mediate between the social system and the physical system. We aim to answer the following questions: Which demands for policy making ont, management of, and research on the Westerschelde arise out of its social environment and which arise out of its physical characteristics, and how did policy making on, management of, and research on the Westerschelde respond to these demands between 1985 and 2006?

The article proceeds as follows. Firstly we identify the characteristics of the social system and the physical system and how, ideally, the policy, management and the research system should deal with these characteristics. We then focus on how these requirements are dealt with by the policy making, management and research systems and what the subsequent effects on the physical system are. Policy making, management and research practices are analyzed in three time frames: from 1985 to 1997, from 1997 to 2001, and from 2001 to 2006. Each of these periods is characterized by unique social and physical dynamics and by visible differences in the way the policy, management and research systems operate. We demonstrate how the approach of policy makers and researchers towards the Westerschelde has evolved from an anthropocentric approach to a more ecocentric approach, combining social and physical challenges within the managing effort. The anthropocentric style focuses on human interests and welfare which can be enhanced by the exploitation of Westerschelde, without explicitly considering the needs of the physical system. The combined adaptive style takes into account the needs of the physical system without forgetting the human needs (Raadgever et al., 2008; Olsson et al., 2006). This style can be contrasted with the so-called ecocentric (from ecology) approach in which the demands of the physical system are prioritised. While a more ecocentric approach could potentially benefit a physical system such as the Westerschelde (cf. Corlay, 1993), we observe that a previously successful combination and integration of all three functions is no guarantee for continued success in the future.

Data is collected from multiple sources. We interviewed 30 participants representing the main actors within the policy, management and science systems, engaged in participative observation during numerous meetings of officials, stakeholders, and experts between 2003 and 2006, and analyzed news papers, policy documents and scientific research reports on the Westerschelde, and particularly on its morphology. Additionally we carried out archival research to reconstruct the decision making process from 1980 to 1998. We asked two independent morphological experts to review our description of the physical system and incorporated their comments in the definite version of this article.

\section{Competing societal demands in the Westerschelde}

Following bilateral agreements and memoranda, there are three main conflicting societal demands current policy makers feel they have to cope with: a need for safety, economic development and ecological sustainability (Memorandum of Kallo, 2001; Vlissingen, 2002).

These social demands are considered to be inherently in conflict by the respondents interviewed for this research. The most obvious conflict seems to be that between economic interests and ecological ambitions. For the several Westerschelde ports, quick, safe and regular access means a deep channel with as little as possible meandering and dampened tidal dynamics to guarantee efficient passage of ships. However, for the ecological-minded, such an approach would be destructive. Extended canalization of the Westerschelde would mean the end of its unique dynamics and of the intertidal areas with their valuable flora and fauna. Economic ambition also conflicts with the desire to guarantee protection from floods: increasing the accessibility of the Westerschelde increases its amount of water (Peters et al., 2000), as well as the energy guided into its narrowly-embanked sections. The inter-tidal areas and the many small tidal channels, on the other hand, help to dissipate most of the tidal energy and reduce the danger of flooding (Peters et al., 2001). Thus, serving one demand works at the expense of others. Ecological and safety interests are much more compatible, although classical approaches on safety are much less tolerant of ecological values (Vroon et al. ,1993).

As stated in several bilateral memoranda (Memorandum of Kallo, 2001; of Vlissingen, 2002; of Den Haag, 2005), these different societal demands have to be accommodated in the policies and management of the Westerschelde. This holds true especially for change to its morphology. They are difficult to integrate because their effects on the constituting elements of the physical system are heavily connected through the morphologic characteristics of the system which include: 
- The shape and depth of the different channels and bars within the channels, including the thresholds where channels cross one another - this is decisive for the accessibility of the ports.

- The amount of inter tidal areas and of low and high dynamic areas - this is important for the system's ecology.

- The fluctuations of tidal changes, the dissipation of tidal energy and the water storage capacity - this is important for the safety of the Westerschelde and the human activity surrounding it.

Because the shape of the channel influences the amount, shape and robustness of the inter-tidal areas, it is difficult to balance economic and ecological demands. Since the shape of the solid barriers, such as dikes, influences the system's tidal dynamics, safety measures aimed at strengthening these barriers affect the system's ecology. Finally, safety measures aimed at giving more space to the estuary (for energy dissipation) enhance the possibilities for the natural system to improve but conflict with public opinion, which holds, according to local newspaper Provinciale Zeeuwse Courant, that setting dikes back diminishes safety. In the Zeeland region removing dikes is strongly associated with the severe impacts of the flood of 1953.

\section{Complexity of physical characteristics of the Westerschelde}

The Westerschelde can be understood as a complex adaptive system (cf. Gerrits, 2008). Its components are connected and it adjusts to changing circumstances (stemming from both human and natural causes). A system is complex when its behaviour is erratic, considerably non-deterministic, and therefore difficult to predict. This limits the ability of policy makers and managers to fully control the system and the ability of researchers to fully understand the system and its future equilibrium states.

We distinguish between endogenous and exogenous complexity. Endogenous complexity refers to complexity generated by the related estuarine components, meaning that a change in one component inluences another component. An example is the dynamic mutual relationship between water and sediment. Deep channels with steep banks concentrate the energy of the water flowing in and out of the Westerschelde, further deepening the channels. This improves accessibility but can also lead to loss of wetlands. Additionally, deepening generates tidal effects which can easily lead to more intensive sedimentation, thereby creating new sand banks.

Exogenous complexity refers to complexity generated by incentives from outside the Westerschelde, such as changes induced by humans to facilitate societal demands. An example is the construction of dykes. Dykes influence the transport of sediment, consequently changing the overall morphology. This sets off a chain of responses throughout the Westerschelde. The same goes for dredging activities. Deepening is worth carrying out if it leads to faster efflux of water. However, it can also lead to new tidal streams that will deliver much more sediment from the river or the sea. Thus, while dyke construction, dredging and aquatic disposal influence the development of the Westerschelde, it is very difficult to predict the causal relations that determine the course of events in the physical system (cf. Peters et al., 2003).

The Westerschelde is characterized by meandering channels that intersect, with shoals and sandbars in between. Its morphology is dynamic - channels and shoals migrate through the Westerschelde due to sedimentation, sediment transport, accumulation and disposal. Sand is imported from the North Sea and, in lesser amounts, from the river in Flanders and France. The channels and bars continue to move throughout the Westerschelde, degenerating and regenerating in an ongoing cycle (Koppel et al., 2003). Human-induced interventions, have an impact on this process (cf. Peters et al., 2003; Gerrits and Marks, 2008), although the magnitude of these impacts is difficult to estimate. The morphological changes are thus influenced by endogenous as well as exogenous complex developments.

The main channels of the Westerschelde are used for navigation. As thresholds of sediments form wherever these channels intersect, maintenance dredging is required to keep these thresholds at the required depth as they obstruct navigation. The dredged material is usually stored in the Westerschelde, either in the secondary channels or on the shoals located in between the channels. Both the shoals and the secondary channels are vital parts of the ecological state of the physical system. Hence, in any human activity, such as the disposal of dredged material, they need to be taken into consideration.

The funnel shape of the Westerschelde means that the energy of the water is concentrated towards the end of the funnel, i.e. at the port of Antwerp (Norga and Souwer, 2003). The presence of a diverse range of areas, such as shallow, deep and intertidal areas, helps dissipate the water's energy, and therefore increases the capacity to absorb a sudden rise in the water level, which is an important feature in this floodprone region (Winterwerp and Jeuken, 2004).

To sum up, there are three dimensions through which the Westerschelde as a physical system can be understood:

1. It is dynamic with regards to the riverbed. Endogenous and exogenous variables change its state continuously, and also change the direction of change. This is the non-linear characteristic of a complex system. Policy makers have to deal with those sudden changes and with the possibilities of system leaps and catastrophes. Small human interventions can have disproportional and selfreinforcing effects on the behaviour of the system. The Seine and the Elbe are clear examples (Gerrits, 2008). 
Table 1. Actor constellations around the Schelde.

\begin{tabular}{lll}
\hline Policy system & Management system & Research system \\
\hline $\begin{array}{l}\text { National governmental } \\
\text { departments (Transport, }\end{array}$ & Directorate General of Public & Delft Hydraulics, Port of Antwerp \\
$\begin{array}{l}\text { Environment, Agriculture); } \\
\text { regional and local authorities, },\end{array}$ & Flemish Ministry on Water. & Technical Committee on the Schelde. \\
$\begin{array}{l}\text { water boards, European } \\
\text { Commission. }\end{array}$ & Dutch Water Boards. & Institute of Coastal and Sea \\
& & Research, independent experts \\
\hline
\end{tabular}

2. It consists of a variety of different components. These components have different and changing attributes. For example, water can be fresh, brackish or salty, sediment consists of different grains, and the depth of the water changes constantly. While the Westerschelde can be used for transport, it can also lead to flooding, help mitigate the impact of high tides, and can be seen as part of a larger feeding system for birds. The multiplicity of the Westerschelde is apparent in how its many components possess a range of attributes, and is reflected in how various human interests are defended in the policy network around the Westerschelde. A high variety of actors are involved in the policy process and attempt to generate support for their claims, related to specific aspects of the Westerschelde.

3. The various components are connected, which means changes in one element affect the other components. Thus, the Westerschelde is best understood as a physical system consisting of connected physical elements. This interconnectedness is an important explanation for the trade-offs made among the different ambitions of the stakeholders who have a stake in the policies regarding the Westerschelde. Improving the accessibility of the port of Antwerp has an impact on whether nature can flourish and could also necessitate additional investments to ensure safety. Thus, other stakeholders are unwilling to agree to channel-deepening investments because their interests could be harmed.

If the overall goal is to manage such a complex system and craft adequate policies for it, thus implying data has to be collected on which policy can be based, the actors involved in the Westerschelde debate have to be able to deal with its complex characteristics (Hooke, 1999; Kay et al., 2003; Folke, 2006; Kotchen and Young, 2007; Bohensky and Lynam, 2005). In the next section we elaborate on the demands that result from the complex physical system characteristics of the Westerschelde for the social system dealing with it. This system can be subdivided into two subsystems: (a) policy making and managing the Westerschelde, and (b) conducting research to obtain knowledge on the physical state of the system, its development and the expected impact of human interventions. Table 1 comprises the main actors who participate in these systems.

\subsection{Requirements of the physical system for the policy-making and management system}

\subsubsection{Non-linearity requires adaptive policies and management}

In non-linear situations, management has to deal with unexpected events and developments, and has to be able to react quickly and flexible to changes. The broad literature on adaptive management (Walters, 1997; Rogers, 1998; Brunner et al., 2005) fits these requirements. Adaptive management "formulates management policies as experiments that probe the responses of ecosystems as people's behavior in them changes" (Lee, 1999) and needs "long-termism", adaptability, precaution and contingency (Stojanovic et al., 2004). To be adaptive, a policy making system has to invest in longterm strategies, respond to changes, and maintain flexibility in the means and ends it uses (Stojanovic et al., 2004). Also, management strategies need to be evaluated in a timely manner, so operations can be adapted as soon as undesirable consequences appear. Policy making is seen as a learning process in which there are possibilities to learn from mistakes.

Adaptive management looks beyond its own timeframe. Policies and strategies need to change when changing conditions require them to do so. In addition, non-linear systems, such as the Westerschelde, require a "trial-and-error" approach to ascertain what works and what does not (Folke et al., 2005; Pahl-Wostl, 2006). This is in contrast to a rigid implementation of a predefined vision with strictly defined policy goals over a long time span which is often dominant in the literature on public management.

\subsubsection{Diversity requires managing competing values}

The diversity of the Westerschelde has both a social and a physical component. They are closely related as the physical system properties affect the realization of specific interests or social demands. Specifically, the navigation channel accommodates the economic function, the inter-tidal areas and the banks are ecologically valuable, and the dikes are necessary 
to safeguard the polders behind the dykes. The water in general accommodates fisheries and recreation activities, and has to be of adequate quality to contribute to the general water quality in the delta.

The physical system thus comprises different societal functions and there are various trades-offs between these functions, which makes them difficult to accommodate simultaneously due to biases in political support, budget constraints, and fragmentation of roles and responsibilities.

These demands are considered being conflicting given the relative limited budget available for the development of the Westerschelde. Realizing one function (safety or accessibility) requires further development of the other functions (ecological value), in order to off-set the possible unfavourable effects of a certain operation or in order to gain broad support among stakeholders. The various functions are represented by powerful stakeholder coalitions that are very well able to defeat one-sided policy decision focussed upon just one aspect. In the case of the Westerschelde, the three societal demands (accessibility, safety and nature quality) have their own protagonists, united in relatively stable actor coalitions, and they compete heavily. Therefore, in order to obtain support for policy measures, it is necessary that policy making is consensus-oriented (Buanes et al., 2004) and that poliy is comprehensive (Stojanovic et al., 2004; Foster and Haward, 2003).

\subsubsection{Interdependence requires managing interconnected subsystems}

In a system in which all components are interconnected, management and policy making focussing on isolated components will fail. Fragmented approaches can have negative effects on the Westerschelde where the fulfilment of its many functions depends on a sound balance between the system's different physical characteristics (Sadoff and Grey, 2002). The preparation and implementation of policy can only be successful once related components, such as dredging, restoring nature and navigation, are integrated, because of the negative effects that one-sided measures (favouring one particular goal) can have on the achievability of other goals in the Westerschelde.

The interconnected character of the different elements of the Westerschelde promotes the use of an integrated approach as is emphasized in the literature on comprehensive water resources management (IWRM) and more specifically on integrated coastal management (ICM). Integrated coastal management is a "multidisciplinary process that unites levels of government and the community, science and management, sectoral and public interests in preparing and implementing a program for the protection and the sustainable development of coastal resources and environments" (UNEP, 1999; Sorensen 1997).

\subsection{Requirements of the physical system for the research system}

The physical characteristics of the Westerschelde also set specific demands on the system of researchers and research institutes investigating it. This research system aims to understand the Westerschelde as a functioning economic entity, as a protection system against flooding, as an ecological system, which boils down to understanding it as an autonomous morphological system. This research system is important as a source of information for policy makers and managers to decide about strategic decisions, but also in the day-to-day management of the estuary. The way this research system functions is of vital importance for the way in which the policy/management system is able to react and anticipate upon the dynamics of the physical system for it provides knowledge input to the policy makers and managers.

\subsubsection{Non-linearity requires longitudinal research}

Firstly, it is important that the research system recognizes the non-linear character of the physical system. It has to take into account the characteristics of systems which are hard to predict. Therefore, research should be carried out over time, instead of focusing on a single point in time. Secondly, it should aim to articulate the range of uncertainties present and, if possible, should help actors become aware of the uncertainties surrounding non-linear systems. Learning by doing or trial-and-error approaches, are the most promising strategies to obtain insights in complex systems (Walters, 1997; Meppem and Gill, 1998). Thus, exploring the main causal relations, longitudinal monitoring and evaluation programs, covering extended time spans are necessary in order to understand the difficult to predict feedback relations within a complex morphological, hydrological and ecological system.

\subsubsection{Diversity requires interactive research}

The diversity of the physical system makes it necessary to organize broad, comprehensive research programs. It also emphasizes the importance of interdisciplinary research and cooperation (Meppem and Gill, 1998). In addition, to take into account the different frames of reference of involved actors, pledges for joint fact-finding are often made (Ehrmann and Stinson, 25). "Joint fact-finding is both a method for sound science-based decision making and a strategy for achieving stable agreements with widespread stakeholder support" (McCreary et al., 2001). The merits of "civic science" or collaborative analysis (cf. Korfmacher, 2002) have been spelt out in coastal management as well. The implication is that research extends beyond scientific research and includes practical knowledge and even lay-knowledge, such as local experience. 
Table 2. Demands on the policy/management and research system.

\begin{tabular}{llll}
\hline & Non-linearity & Diversity & Interdependence \\
\hline $\begin{array}{l}\text { Demands on } \\
\text { policy and } \\
\text { management } \\
\text { system }\end{array}$ & $\begin{array}{l}\text { Adaptive management: } \\
\text { mutual adjustment, trial } \\
\text { and error, flexible and } \\
\text { non-blue-print }\end{array}$ & $\begin{array}{l}\text { Consensual management: } \\
\text { trying to find solutions } \\
\text { that serve the interests of } \\
\text { as many as possible } \\
\text { aspects }\end{array}$ & $\begin{array}{l}\text { Integrated management: } \\
\text { trying to surpass territorial } \\
\text { and functional cleavages, } \\
\text { cooperation, coordination }\end{array}$ \\
\hline $\begin{array}{l}\text { Demands on } \\
\text { research system }\end{array}$ & $\begin{array}{l}\text { Learning by doing } \\
\text { Long-term monitoring } \\
\text { Uncertainty management }\end{array}$ & $\begin{array}{l}\text { Joint fact-finding, } \\
\text { interactive science. }\end{array}$ & $\begin{array}{l}\text { Interdisciplinary and } \\
\text { collaborative research }\end{array}$ \\
& & & \\
\hline
\end{tabular}

\subsubsection{Interdependency of the morphology's elements requires interdisciplinary research}

The dynamic interdependency between the different elements, such as the interdependency between sedimentation and biota in the physical system, requires an interdisciplinary approach towards research and monitoring. Morphological, hydrological and ecological insights should be developed in close interaction with each other to integrate knowledge about the relations between the different aspects of the system, because these disciplines represent tightly connected physical subsystems. In addition, a mixed scanning approach (Etzioni, 1967) can be useful: attempting to gain a more complete insight into the physical system, while focusing on the relevant details when specific policy decisions have to be made.

The effects of the physical and social characteristics on policy-making, management and research are summarized in Table 2.

To analyze management and research practices empirically in the case study, it is necessary to specify the above requirements further. We do this by developing two ideal types that represent the two extreme positions with regard to these requirements:

a. Policy making/management: non-adaptive management versus adaptive management; fragmented versus integrated management; unilateral and top-down versus consensual management (see Table 3); and:

b. Research: comprehensive design approach versus learning-by-doing; solitary disciplinary versus collaborative interdisciplinary research; and expert rule (authoritative but mandated science) versus joint factfinding (see Table 4).

\section{Case: developing the Westerschelde}

The question we are focused on is whether and how the afore-mentioned requirements are reflected in the policy and management system of the Westerschelde and whether we can witness an evolution in the fit between this system and the physical system during the last two decades. This period has been marked by clear changes in the policy, management and research system, and the different phases of this change are analyzed and compared in the light of this fit. The differing management and research styles are related to the main developments of the Westerschelde as a physical system.

\subsection{5-1997: opposing neighbours and laborious negotiations}

\subsubsection{Policy making and management}

In the 1980 s the management and policy-making of the Westerschelde proved to be troublesome, especially with regards to discussions about deepening the main channel from Vlissingen to Antwerp, a request by the Flemish authorities in 1981. The Dutch government was not eager to deepen the channel as it could lead to a deterioration of the province of Zeeland's ecology, which would have to be compensated. Additionally, they feared not to benefit from the larger channel and increased transport to Antwerp. Both countries regarded eachother from a negative viewpoint, with the Dutch accusing the Belgians of collecting the profit from a deepening project and the Belgians accusing the Dutch of hindering their economic development at the advantage of Dutch ports. The final decision was taken in 1995, as part of a package deal between both countries connecting two totally different issues.

As a result of the tensions in bilateral and intergovernmental relations, the Westerschelde was managed in a fragmented way, in terms of its functionality as well as scale. While research was strictly divided into Dutch and Flemish subsystems, co-operation between the Dutch and Flemish policy makers and managers was politicized or strictly bureaucratic. Specifically, the Flemish were responsible for the maintenance of the navigation channel, and the Dutch gave them the necessary permit for the dredging and disposal activities and monitored the effects. 
Table 3. Contrasting management styles to deal with physical systems.

\begin{tabular}{ll}
\hline Anthropocentric policy and management style & Adaptive policy and management style \\
\hline $\begin{array}{l}\text { Non-adaptive management: management based } \\
\text { on political or technical ambitions: }\end{array}$ & $\begin{array}{l}\text { Adaptive management: management tries to } \\
\text { respond to and anticipate the behaviour of the } \\
\text { physical system: }\end{array}$ \\
\hline $\begin{array}{l}\text { Policy ambitions are based on political or other } \\
\text { ideals and are rigorously implemented }\end{array}$ & $\begin{array}{l}\text { Central question is: how can political ambitions be } \\
\text { combined with the characteristics of the physical } \\
\text { system, and carried out with respect to these } \\
\text { characteristics? }\end{array}$ \\
\hline $\begin{array}{l}\text { Fragmented management: organisations } \\
\text { involved execute their own job, without paying } \\
\text { attention to the tasks and priorities of other } \\
\text { organisations: }\end{array}$ & $\begin{array}{l}\text { Comprehensive management: organizations } \\
\text { involved try to coordinate their actions in order to } \\
\text { realise collective ambitions: }\end{array}$ \\
\hline $\begin{array}{l}\text { Few, if any, contacts between organizations and few } \\
\text { if any arrangements for interaction }\end{array}$ & $\begin{array}{l}\text { Decisions are made by consulting and activating the } \\
\text { different organisations involved in the policy and } \\
\text { implementation network }\end{array}$ \\
\hline $\begin{array}{l}\text { Unilateral management: central (principal) } \\
\text { organisation makes crucial decisions } \\
\text { unilaterally: }\end{array}$ & $\begin{array}{l}\text { Consensual management: stakeholders and officials } \\
\text { try to reach broadly-supported decisions: }\end{array}$ \\
\hline $\begin{array}{l}\text { Decisions are made by political central bodies } \\
\text { parliament, ministers). Regional governments and } \\
\text { stakeholders are marginally involved or not at all. }\end{array}$ & $\begin{array}{l}\text { Collaboration between governments and stakeholders } \\
\text { Actors try to reach shared ambitions and/or package } \\
\text { deals }\end{array}$ \\
\hline
\end{tabular}

The policy and management system was characterized by a strongly divided approach: a few highly specialized agencies managed the Westerschelde, in close interaction with public research institutes. Much dissatisfaction among diverse interest groups existed with this approach. Many of them believed that, during this period, economic interests were given higher priority over ecological values. Additionally, decentralized governments and interests groups on the Dutch side of the Westerschelde felt they were neglected during the negotiations. Since the voices of the environmental interest groups were not heard, they fought out their conflicts with governmental agencies in judicial institutions (cf. Meijerink, 1998), when the deal to deepen the estuary was made.

The Technical Commission on the Schelde, responsible for the daily management of the Schelde, was a technocratic body and was positioned high in the hierarchy of the national civil services. Consequently, their attention to local and regional interests was low. The Westerschelde was much more of a negotiable asset for international diplomacy than the joint responsibility of two countries, and the ecology dimension never was a major issue for them. Thus, an anthropocentric management style dominated in this period. Table 5 presents the main characteristics of this management style.

\subsubsection{Research system}

Similar to the management and policy making system, the research system was subject to fragmentation and lack of co-operation. Expertise from both sides was not used optimally because of the strong institutional cleavages between both nations. The Dutch had built up a strong but relatively closed research system. The various knowledge institutes and the water management authorities developed and maintained tight relations and their employees frequently switched between the various organizations in this system. However there was much less border traffic between the research network and the outer world. The standards of knowledge and technology were high, but technocratic and unresponsive to other opinions. Cooperation with Belgium was lacking due to the differences in methods and assumptions but also due to the closed nature of the Dutch sciencepolicy network. Flemish research on morphology at that time lagged the Dutch, which hindered co-operation. An example of this is the research project East-West, which referred to the eastern part of the Westerschelde were morphological stagnation had occurred. Although both countries possessed the solution for the problem, the project was a solely Dutch affair for a long time before the Belgians participated. Interaction with other stakeholders, namely environmental interest groups, was absent. Finally, experts were mobilized 
Table 4. Contrasting research styles to deal with physical systems.

\begin{tabular}{|c|c|}
\hline Anthropocentric research style & Ecocentric research style \\
\hline $\begin{array}{l}\text { Design approach: research develops tools that make the } \\
\text { realization of political or technical ambitions possible, } \\
\text { without serious attention to the physical behaviour of } \\
\text { the system; researchers investigate the optimal use of } \\
\text { the Westerschelde for humans }\end{array}$ & $\begin{array}{l}\text { The physical system is perceived as a living system } \\
\text { with its own needs and behaviour. The vitality of the } \\
\text { morphological system is investigated, along with human } \\
\text { needs. }\end{array}$ \\
\hline $\begin{array}{l}\text { Research questions are deduced from policy ambitions } \\
\text { and meant to answer to the question: how can we } \\
\text { implement this solution? Research output is handed } \\
\text { over from the research to the policy/management } \\
\text { system }\end{array}$ & $\begin{array}{l}\text { Research is based on the complex and dynamic } \\
\text { interrelation between elements and subsystems. } \\
\text { Research is integrated in the policy process and, during } \\
\text { the interaction, policy ambitions and methods are } \\
\text { developed. Practice leads. }\end{array}$ \\
\hline $\begin{array}{l}\text { Disciplinary research: focusing on the reality of a single } \\
\text { organization that is doing its own job. }\end{array}$ & $\begin{array}{l}\text { Interdisciplinary research focusing on the multiple } \\
\text { realities of several involved organizations and } \\
\text { combining the variety of insights and knowledge into a } \\
\text { joint understanding of collective needs and actions. }\end{array}$ \\
\hline $\begin{array}{l}\text { Focus on disciplinary research within own institute, } \\
\text { within one framework of assumptions, models and } \\
\text { practices. Little interaction between research institutes } \\
\text { and between disciplines (normal science) }\end{array}$ & $\begin{array}{l}\text { Research is set up around comprehensive research } \\
\text { questions and in an interdisciplinary, or at least } \\
\text { multidisciplinary, research program. Collaboration } \\
\text { between different (competing) research institutes (mode } \\
\text { two science) }\end{array}$ \\
\hline $\begin{array}{l}\text { Expert rule: dealing with the needs of the principal as } \\
\text { distinctively as possible. }\end{array}$ & $\begin{array}{l}\text { Joint fact-finding: the research process is set up in close } \\
\text { interaction with stakeholders and officials }\end{array}$ \\
\hline $\begin{array}{l}\text { Political or societal interference in the research process } \\
\text { is rejected. No negotiations about and adjustments of } \\
\text { research results possible. } \\
\text { Experts protect their expertise and conclusions from the } \\
\text { opinions of stakeholders. }\end{array}$ & $\begin{array}{l}\text { Stakeholders involved in the research process: } \\
\text { formulation of research questions, selection of data, } \\
\text { models and interpretation methods, formulation of } \\
\text { conclusions }\end{array}$ \\
\hline
\end{tabular}

Table 5. Management style 1985-1997.

\begin{tabular}{ll}
\hline Non-adaptive management: & $\begin{array}{l}\text { Anthropocentric management style } \\
\text { Political negotiated ambitions prevail in management. Physical } \\
\text { developments in the Westerschelde are little-known and not taken into } \\
\text { account in policy development and management. Political deals are } \\
\text { marginally evaluated for their impact on the physical system. }\end{array}$ \\
\hline Fragmented management: & $\begin{array}{l}\text { Little interaction between Flemish and Dutch governmental bodies. Both } \\
\text { governments defend their own interests. No integration between regional, } \\
\text { national and aspect-specific ambitions: functional and territorial } \\
\text { fragmentation. Ambitions of stakeholders remain opposite. }\end{array}$ \\
\hline Unilateral management: & $\begin{array}{l}\text { Led by the managerial decisions of the TCS and the political decisions of } \\
\text { ministers. No serious involvement of other actors. }\end{array}$ \\
\hline
\end{tabular}

pragmatically by decision-makers: the ultimate decision to deepen the channel was taken without a serious environmental impact assessment (Meijerink, 1998). Table 6 represents the main elements of this anthropocentric research approach.

\subsubsection{Physical changes}

This period was marked by a number of physical changes. The surface of the intertidal areas continued to decrease, a development that began some years earlier. The number of 
Table 6. Research style 1985-1997.

\begin{tabular}{ll}
\hline \multicolumn{1}{c}{ Anthropocentric research style } \\
\hline Design approach & $\begin{array}{l}\text { Political decisions lead, as science is used to guide the implementation } \\
\text { trajectory. }\end{array}$ \\
\hline Fragmented research & $\begin{array}{l}\text { Interdisciplinary insight in complex interactions in physical system is not } \\
\text { developed. There is no interaction between institutes of different countries: } \\
\text { they use their own methods, data et cetera. }\end{array}$ \\
\hline Expert rule & $\begin{array}{l}\text { No discussion about scientific procedures. Knowledge of own institutes is not } \\
\text { confronted with counter knowledge. No interaction with other actors. }\end{array}$ \\
\hline
\end{tabular}

shallow water areas also decreased continuously. Another indicator for a change from a multi-channel system towards a single-channel system is the erosion and ensuing transport of sediments, highlighting sand imports from the North Sea occurred during this period. The suspended material in the Westerschelde fluctuated over time, increasing one year and diminishing the next. This was closely related to the sand mining operations. However, the suspended material was mainly found outside the navigation channel, a sign that the secondary channels were silting up. Finally, the tidal range continued to increase. This first period ended with the start of dredging operations to deepen the navigation channel.

\subsection{8-2001: cautiously together}

\subsubsection{Policy making and management}

The decision to deepen the Westerschelde caused many legal and budgetary problems and the situation dissatisfied many actors. Before the deepening of 1997 had been completed, the Port of Antwerp had already expressed a desire for further deepening of the navigation channel. In order to avoid the weaknesses and pitfalls of the previous decision making process, the Ministers of both governments decided in 1999 to develop a Long Term Vision or LTV on the Westerschelde, marked by close co-operation between both governments and stakeholders. The fragmented and relatively pragmatic policy strategy was abandoned. It was felt that any further deepening needed to fit into an integrated policy for the Westerschelde. An extensive trajectory of research, deliberation and negotiation resulted in a broadly supported LTV in which five policy ambitions for the year 2030 were put down:

1. Preserving the physical system characteristics of the Westerschelde;

2. Safeguarding the economic interests of the different ports;

3. Prevention against floods in Zeeland;

4. Improving the ecological situation of the Westerschelde;

\section{Prolific and sustainable co-operation.}

A concrete action program was formulated to realize this long-term vision. However, the process leading to the LTV was not without shortcomings. Firstly, the way in which the research process developed was troublesome. The morphological research for estimating the future development of the Westerschelde and the possible effects of a deepening on its morphology was set up and carried out exclusively by Dutch experts and research institutes. The Port of Antwerp responded by setting up a parallel research project in the form of the Port of Antwerp Expert Team. Both knowledge processes remained separated and no joint analysis occurred.

Another important shortcoming was, again, the nonparticipation of regional governmental actors. The LTV was first and foremost the product of national governments and their specialised agencies. They learned from the period prior to 1995 and involved interest groups in their deliberations to a certain extent, although decentralized governments were not invited.

Third, the LTV process was developed and managed by a small civil project team that stayed within existing organisations and did not reach out to other parties. That did not help arriving at an integrated management structure because existing institutional routines and organisational interests were too dominant to make an effective collaborative process possible. The development of the Long Term Vision was also a very formal and political process in which little room for open, collaborative dialogue between the different governmental agencies and the stakeholders was possible.

We see the management style as having developed somewhat from the previous period. Although there are tendencies towards a more adaptive, comprehensive, and consensual approach, they were a little half-hearted. The system was in a transition phase as is highlighted in Table 7.

\subsubsection{Research system}

The way in which research was utilized for the LTV showed the same ambivalence. Experts saw it as their role to deliver the information officials need to make decisions. However, 
Table 7. Management style 1998-2001.

\begin{tabular}{ll}
\hline \multicolumn{1}{c}{ Mixed management style } \\
\hline Semi-adaptive management & $\begin{array}{l}\text { More adaptive: physical system characteristics are points of departure for } \\
\text { formulating policy ambitions (ambition 1 of LTV) }\end{array}$ \\
\hline $\begin{array}{l}\text { Semi-comprehensive } \\
\text { management }\end{array}$ & $\begin{array}{l}\text { Cautious start of more integrated management through the start of an } \\
\text { interorganizational project team. But little interaction with regional } \\
\text { governments and stakeholders. }\end{array}$ \\
\hline $\begin{array}{l}\text { Semi-consensual } \\
\text { management }\end{array}$ & $\begin{array}{l}\text { Stakeholders involved, but decision-making is highly focused on } \\
\text { ministers and TCS. Ultimate decision is package deal on international } \\
\text { level }\end{array}$ \\
\hline
\end{tabular}

Table 8. Research style 1998-2001.

\begin{tabular}{ll}
\hline \multicolumn{1}{c}{ Anthropocentric research style } \\
\hline Design approach & $\begin{array}{l}\text { Design approach: how to combine the different policy ambitions? No critical } \\
\text { reflection upon policy questions or attention to alternative options/measures }\end{array}$ \\
\hline Fragmented research & $\begin{array}{l}\text { Fragmented research: no interdisciplinary research and no coordination between } \\
\text { national institutes }\end{array}$ \\
\hline Self-referential science & No serious stakeholder involvement in research process. \\
\hline
\end{tabular}

the research was not very detailed, and was more conceptual and approximate. Additionally, external reviews of the different research projects were very critical of the lack of coordination and cooperation between the different disciplines. The lack of serious stakeholder involvement accounted for stakeholders to become dissatisfied with the quality of the research results used to develop the LTV quickly. The research style is anthropocentric.

\subsubsection{Physical changes}

The main physical change was the deepening that took place between 1997 and 1998. However, the results from this deepening, apart from the new depth, are not clearly reflected in the data, as morphological changes take considerable time to become visible. The total surface area of the intertidal areas continued to decrease, and at a faster pace than before the deepening. The decrease of shallow-water areas continued as well, but it was at a steadier pace than the decrease of the inter-tidal areas. Sand import changed to sand export, i.e. more sand was transported to the North Sea or gained through sand mining than was imported from the sea. 1998 was the last year for which sand was imported; after that, it becomes an export product. This is the clearest change observed in the time span of this case. The volume of suspended material in the secondary channels continued to increase.

\subsection{1-2006: interactive and connected}

\subsubsection{Policy making and management}

The Long Term Vision was approved by the Flemish and Dutch governments. They agreed that, for the year 2010, a concrete Development Plan containing an integrated package of measures to realize a substantial part of the Long Term Vision had be delivered by a Dutch-Flemish project organization by the end of 2004 .

A project organization called ProSes was established. This organization set up an intensive deliberation and negotiation process. The policy process was organized in collaboration with different stakeholders, including the Port of Antwerp, environmental pressure groups, and governmental bodies.

The content of the Development Plan (issued at the end of 2004) reflected the high level of uncertainty about the possible effects of human intervention on the Westerschelde. A special protocol was set up to deal with the hypothetical situation of the dredging activities leading to degeneration of the multi-channel system. Also, a long-term monitoring and research project was established to monitor the morphological developments within the Westerschelde during and after the deepening.

As suggested by the Port of Antwerp Expert Team, the Development Plan also contained an experiment with an alternative dredging and disposal strategy, called "morphological dredging". This alternative took an offensive approach 
Table 9. Management style 2001-2006.

\begin{tabular}{ll}
\hline Reflexive management & \multicolumn{1}{c}{ Combined adaptive management style } \\
& $\begin{array}{l}\text { More adaptive: physical system characteristics are points of departure for } \\
\text { formulating policy ambitions. Flexible dumping strategy is part of policy. } \\
\text { Also, alternative ways of dredging are allowed because of the proven } \\
\text { weaknesses of the current rigid dredging permit. }\end{array}$ \\
\hline $\begin{array}{l}\text { Comprehensive } \\
\text { management }\end{array}$ & $\begin{array}{l}\text { More comprehensive management through semi-permanent and inclusive } \\
\text { project structure. Enduring collaboration of different governmental } \\
\text { authorities and stakeholders. }\end{array}$ \\
\hline $\begin{array}{l}\text { Management of } \\
\text { competing values }\end{array}$ & $\begin{array}{l}\text { Stakeholders have an official position in policy process and subsequent } \\
\text { management trajectory. To some extent, Development Plan contains } \\
\text { attractive elements for all parties and serves the various functions of the } \\
\text { estuary. }\end{array}$ \\
\hline
\end{tabular}

Table 10. Research style 2001-2006.

\begin{tabular}{ll}
\hline \multicolumn{1}{c}{ Moderate adaptive research style } \\
some learning by doing & $\begin{array}{l}\text { Design approach but also trial-and-error: official institutes focus on answering } \\
\text { research questions derived from policy ambitions. Alternative research focuses } \\
\text { on experiments and innovative dredging approaches. }\end{array}$ \\
\hline Interdisciplinary research & $\begin{array}{l}\text { First attempts at interdisciplinary and bilateral research. Establishment of an } \\
\text { extensive interdisciplinary research project with close cooperation between the } \\
\text { various disciplines. }\end{array}$ \\
\hline Joint fact-finding & $\begin{array}{l}\text { Stakeholders advise the experts. Parallel research is intertwined with the official } \\
\text { research, much is invested in integrated expert and practical knowledge. }\end{array}$ \\
\hline
\end{tabular}

by focusing on nature restoration through dredging and both aquatic and inland disposal and careful monitoring. This trial-and-error approach was completely different from existing policy in which dredged material could only be dumped within fixed locations, with negative consequences on the dynamics of the system (Peters et al., 2003).

Since the previous deepening, most parties involved seemed to have understood the weaknesses of that particular decision-making process. The current process showed considerable improvement over the previous approach. First of all, the degree of support for the proposed measures was considerably larger. The package deal (a combination of deepening, developing nature, and investing in safety) was acceptable for most actors. Only the regional authorities of Zeeland disagreed with the Development Plan. However, in return for national funding for socio-economic investments, they agreed to refrain from (juridical) resistance against a further deepening of the Westerschelde.

Secondly, there was no major controversy over the main research findings regarding the morphology of the Westerschelde. This can be called a major result, given the high number of controversies which had risen in the past between different actors.
The most important problem regarding the Development Plan was the low attention given to agricultural interests, which at present hinders the implementation of the nature development proposals: the creation of floodplains by relocating dikes inland at the expense of farmland. Because of the passive involvement of the agricultural interest group, no measures had been developed that integrated agriculture with nature conservation.

The Development Plan reflects some characteristics of adaptive management. The actors agree that, once undesirable effects of the deepening appear, the intended operations should be altered or abandoned. Also, attention was paid to the potential of using a trail-and-error approach, especially with regard to the dredging and disposal strategy.

The form of the project organisation proved to function well for an integrated approach, as it incorporated the interdependencies of the different aspects of the Westerschelde through the involvement of almost all relevant actors. However, the limited involvement of agricultural interests and the organizations in charge of water management (the Water Boards) remains a weakness of the ProSes approach, especially with regard to the nature conservation proposals. Nature conservation requires the transformation of farmland 
(which is why the agriculture organizations need to be involved) and changes to the water system (which is the responsibility of the Water Boards). After a while, their resistance to the proposals was supported by the Dutch Parliament, which delayed approval of the Development Plan before the nature projects were amended in favour of agricultural interests. See Table 9 for a short characterization.

\subsubsection{Research system}

The research to underpin the Development Plan was organized in close interaction with stakeholders but also in a truly interdisciplinary research team. The Port of Antwerp Expert Team participated in Working Groups and expert panels. Their ideas for a more empirical and experimental approach toward understanding the Westerschelde were integrated in the final Development Plan. PAET proposed a large-scale insitu test to map the actual reaction of the system on human intervention. This research project was intertwined with the formal strategic environmental impact assessment. The decision to deepen the navigation channel was accompanied by a decision to set up a long-term monitoring program to keep an eye on the system and its behaviour after this intervention. It was agreed that, if negative developments occurred, the deepening would be cancelled. Table 10 summarizes the research style in this period.

\subsubsection{Physical changes}

It is difficult to obtain meaningful analysis of the physical changes during this period as the data has not been processed yet. Sand exports appear to have continued. The question of whether more sand will be imported or exported in the near future remains unanswered. There also appears to be a trend towards more flood dominance, although more data is needed to confirm this observation. A direct operation is an empirical test at the Walsoorden location, during which dredged material is applied to the tip ends of the shoal to regenerate its capacity to maintain itself. The test has been deemed to be successful, which in turn opens up the possibility of extending this strategy elsewhere in the Westerschelde during the future broadening.

\section{Conclusions: congruence between the physical system characteristics and the policy, management and research system?}

Throughout the years, the actors involved in managing the Westerschelde gradually shifted from the anthropocentric approach towards an ecocentric approach. For example, societal actors have developed a more cooperative strategy to align their own goals with the physical development of the Westerschelde. Also, researchers and policy makers recognize joint fact-finding and long-term monitoring is necessary to deliver adequate knowledge on the evolution of the estuary.

Recently, the management of the Westerschelde has adjusted its proposals and strategies to match the requirements of the physical system. This became possible since the main physical changes are better understood compared to the past and are better communicated with the policy and management system. This approach, which increasingly accepts the complexity of the physical system, is applied to prevent unforeseen and unfavourable effects following the deepening operation (or other man-made changes) and to safeguard the ecological state of the system. It has become the point of departure for policy and management and that is a clear change from the past.

When the demands placed on the social system by the physical system are compared over the past two decades of policy, management and research on the Westerschelde, a learning effect can be observed. This first became visible when the Long Term Vision was prepared, and has, even though some weaknesses remain, become clearer during the last few years when the ProSes organisation was operating.

We witness a number of tell-tale signs that illustrate a growing congruence between management and research and the physical characteristics of the Westerschelde.

- The anthropocentric dredging and disposal strategy of the 1990s has been abandoned because of its unfavourable effects on the system's natural state. It led, among other things, to the immobilisation of sediments and strains on the multi-channel character of the system. A more adaptive morphological management strategy has been developed. The experimental testing of disposal strategies is a new adaptive strategy that appears to work better than the former (rigid and fixed) dumping strategy that resulted in a stiffening of the eastern part of the Westerschelde.

- The combined style based on the idea that ecological development and accessibility are not a priori adversaries, but can benefit from each other, was operationalized in the so-called "morphological dredging" technique. This method could be developed because of the more consensual, adaptive and integrated behaviour of the policy, management and research systems.

- Contact between ecological and morphological experts from different disciplines generated a more comprehensive view of the ecological value of different aspects of the Westerschelde. Dutch morphological research traditionally focuses on macro-dynamic processes within the riverbed, while ecologists are interested in microdynamic processes in specific ecologically-valuable areas. This detailed focus provided for added value, as it helps to find and allocate potential locations for nature development. 
- The joint fact-finding process of ProSes forced researchers working with computational models to acknowledge the value of in-situ experiments. This made a more refined intervention approach possible, in which fine-tuned human interventions guided the physical processes.

- The current main actors in the social system that interacts with the Westerschelde understand each function of the physical system has to be regarded in relation to other functions. This view is now held among both governments and stakeholders. Consequently, these functions are included in package deals. Anthropocentric decisions to deepen the navigation channel without looking at the unfavourable effects are not longer deemed acceptable.

- The negotiations over the current proposals include investments in research and monitoring, nature development and safety measures. There is also more attention to the uncertainties and risks of deepening. The interdisciplinary and bilateral monitoring program will be more able to detect negative developments within the Westerschelde at an early stage.

\section{Reflection}

Central to this article is the mutual interaction between social and physical systems and the way the variety of demands that stem from both systems can be accommodated by policy makers, managers and researchers by adjusting their style of policy making, management and research. By doing so, actors learn to cope with the dynamics of the Westerschelde more consciously. Actors develop new ways of operating, new frames of mind and more precise interpretations of the behaviour of the physical system. This increasingly adaptive approach is valuable as it helps to deal with the multiple conflicts.

However, fallback will occur as soon as new (political) actors entering the social systems again view the Westerschelde as a bargaining asset, and policy agencies and research institutes regard the physical system solely as their engineering challenge. The first signs of this fallback are already visible at the time of writing. Renewed fierce societal and political resistance against the various projects necessary to implement the agreement for nature restoration can be found, even though there was initial agreement. Therefore the proposed nature development runs the risk of being delayed or marginalized. If that happens and the deepening is pushed through, nature restoration will not take place and the physical characteristics of the Westerschelde may be threatened. The measures being proposed now are already less farreaching then originally intended in the Developmental Outline. During summer 2009 the Dutch government received a decision of the High Court forbidding the deepening for it was not clear whether sufficient new estuarine nature could be developed to compensate for the deepening. This caused the national government to select a specific polder for estuarine development, despite considerable public protest. This incident shows the fragility of the newly established consensus over goals for economy and ecology. The deepening operations have started at the time of writing (autumn 2010) but the nature development projects are marginal and develop slowly.

A reflection on our analysis should take into account that our focus on the formal three functions of the estuary, as formulated in a string of policy documents, has narrowed our research focus. It leaves out the agricultural functions situated on the banks of the Westerschelde, in a similar fashion of how the policy process did not address the farmers and their needs. The consequences are clear: the trade-off to accommodate accessibility, environment and safety is with the farmers who have to hand in their land for estuarine development. A truly adaptive approach to the estuary also has to take into account the difficult trade-offs between the official policy aims and the oftentimes ignored agricultural values.

Acknowledgements. We wish to extend our sincere gratitude to Leo Santbergen (Water Board Brabantse Delta) and Wim van Densen (Wageningen University) for their expertise and reviews of earlier versions of this article. We also thank the reviewers of HESS for their thorough reviews. We take sole responsibility for the errors and interpretations in this article. Edited by: P. van der Zaag

\section{References}

Bohensky, E. and Lynam, T.: Evaluating responses in complex adaptive systems; insights on water management from the Southern African Millennium Ecosystem Assessment, Ecol. Soc., 10(1), 11, 2005.

Brunner, R. D., Steelman, T. A., Coe-Juell, L., Cromley, C. M., Edwards, C. M., and Tucker, D. W.: Adaptive governance; integrating science, policy, and decisionmaking, New York, Columbia University Press, 2005.

Buanes, A., Jentoft, S., Karlsen, G. R., Maurstad, A., and Søreng, S.: In whose interest? An exploratory analysis of stakeholders in Norwegian coastal zone planning, Ocean Coast. Manage., 47, 207-223, 2004.

Corlay, J. P.: Coastal wetlands: a geographical analysis and some projects for management, Ocean Coast. Manage., 19, 17-32, 1993.

Ehrman, J. R. and Stinson, B. L.: Joint fact-finding and the use of technical experts, in: The consensus building handbook; a comprehensive guide to reaching agreements, edited by: Susskind, S., McKearnan, S., and Thomas-Larmer, J., Sage, Thousand Oaks, 375-400, 1999.

Etzioni, A.: Mixed-Scanning: a "Third" Approach to DecisionMaking, Public Admin. Rev., 27, 385-392, 1967.

Folke, C., Hahn, T., Olsson, P., and Norberg, J.: Adaptive governance of social-ecological systems, Ann. Rev. Environ. Resour., 30, 441-473, 2005. 
Folke, C.: Resilience; the emergence of a perspective for socialecological systems analysis, Global Environ. Change, 16, 253267, 2006.

Foster, E. G. and Haward, M.: Integrated management councils; a conceptual model for ocean policy conflict management in Australia, Ocean Coast. Manage., 46, 547-563, 2003.

Gerrits, L.: The Gentle Art of Coevolution. A complexity theory perspective on decision making over estuaries in Germany, Belgium and the Netherlands, Erasmus University Rotterdam, Rotterdam, 284 pp., 2008.

Gerrits, L. and Marks, P. M.: Complex bounded rationality in dyke construction, Land Use Policy, 25, 330-337, 2008.

Gerrits, L., Marks, P. M., and Van Buuren, M. W.: Co-evolution: a constant in non-linear thinking, in: Managing complex governance systems, edited by: Teisman, G., Van Buuren, M. W., and Gerrits, L., Routledge, 154-171, 2009.

Hooke, J. M.: Decades of change; contributions of geomorphology to fluvial and coastal engineering and management, Geomorphology, 31, 373-389, 1999

Huda, A. T. M. S.: Interagency collaboration for integrated coastal zone management; a Bangladesh case study, Coast. Manage., 32, 89-94, 2004.

Innes, J. E. and Booher, D. E.: Consensus building and complex adaptive systems; a framework for evaluating collaborative planning, J. Am. Plann. Assoc., 65, 412-423, 1999.

Kay, R., Alder, J., Brown, D., and Houghton, P.: Management cybernetics; a new institutional framework for coastal management, Coast. Manage., 31, 213-227, 2003.

Koppel, J., Rietkerk, M., Dankers, N., and Herman, P. M. J.: ScaleDependent Feedback and Regular Spatial Patterns in Young Mussel Beds, Am. Nat., 165, 66-77, 2003.

Korfmacher, K. S.: Science and ecosystem management in Albemarle-Pamlico Estuarine Study, Ocean Coast. Manage., 45, 277-300, 2002.

Kotchen, M. L. and Young, O. R.: Meeting the challenges of the anthropocene; towards a science of coupled human-biophysical systems, Global Environ. Change, 17(2), 149-151, 2007.

Lee, K. N.: Appraising adaptive management, Conservation Ecology, 3, http://www.consecol.org/vol3/iss2/art3, last access: 1 May, 2008.

McCreary, S., Gamman, J., Brooks, B., Whitman, L., Bryson, R., Fuller, B., McInerny, A., and Glazer, R.: Applying a mediated negotiation framework to integrated coastal management, Coast. Manage., 29, 183-216, 2001.

Meijerink, S. V.: Conflict and cooperation on the Scheldt River Basin; a case-study of decision making on international Scheldt issues between 1967 and 1997, Delft Technical University, Delft, 1998.

Memorandum van Kallo: Memorandum van overeenstemming tussen Vlaanderen en Nederland met betrekking tot de onderlinge samenwerking ten aanzien van het Schelde - Estuarium, Kallo, 5 February, 2001.

Memorandum van Vlissingen: Tweede memorandum van overeenstemming tussen Vlaanderen en Nederland met betrekking tot de onderlinge samenwerking ten aanzien van het Schelde - Estuarium, Vlissingen, 4 March, 2002.

Meppem, T. and Gill, R.: Planning for sustainability as a learning concept, Ecol. Econo., 26, 121-137, 1998.
Norga, K. and Souwer, C.: Naar een nieuw Sigmaplan; kennismaking met het Zeescheldebekken, Antwerpen, 2003

Olsson, P., Gunderson, L. H., Carpenter, S. R., Ryan, P., Lebel, L., Folke, C., and Holling, C. S.: Shooting the rapids; navigating transitions to adaptive governance of social-ecological systems, Ecol. Soc., 11(1), 18, 2006.

Pahl-Wostl, C.: Transitions towards adaptive management of water facing climate and global change, Water Resour. Manag., 21(1), 49-62, 2006.

Peters, J. J., Meade, R. H., Parker, R., and Stevens, M. A.: Westerschelde baseline report, Antwerpen, Port of Antwerp Expert Team, 2000.

Peters, J. J. and Parker, W. R.: A strategy for managing the Westerschelde's morphology, Draft report for discussion, An addendum for the final report, Antwerpen, Port of Antwerp Expert Team, 2001.

Peters, B. G. T. M., Liek, G. A., Wijsman, J. W. W., Kuiper, M. W. M., and van Eck, G. T.: Monitoring van de effecten van de verruiming 48'/43', Middelburg, RIKZ, 2003.

Peters, J. J.: Proposals for managing the morphology of the Westerschelde, Antwerpen, Port of Antwerp Expert Team, report 32, 2003.

Poitras, J., Bowen, R., and Wiggin, J.: Challenges to the use of consensus building in integrated coastal management, Ocean Coast. Manage., 46, 391-405, 2003.

Projectbureau LTV: Langetermijnvisie Schelde - Estuarium, RA 100-445, Januari, 2001.

ProSes: Vogel- en Habitattoets Ontwikkelingsschets 2010 Schelde - Estuarium, Bergen op Zoom, Januari, 2005.

Raadgever, G. T., Mostert, E., Kranz, N., Interwies, E., and Timmermans, J. G.: Assessing management regimes in transboundary River basins; do they support adaptive management, Ecology and Society 13(1):14, http://www.ecologyandsociety.org/vol13/ iss 1/art14/, last access 1 May, 2008.

Rogers, K.: Managing science/management partnerships; a challenge of adaptive management, Conserv. Ecol., 2, 1, 1998.

Sadoff, C. W. and Grey, D.: Beyond the river; the benefits of cooperation on international rivers, Water Policy, 4, 389-403, 2002.

Sorensen, J.: National and international efforts at integrated coastal management; definitions, achievements and lessons, Coast. Manage., 25, 3-41, 1997.

Stojanovic, T., Ballinger, R. C., and Lalwani, C. S.: Successful integrated coastal management; measuring it with research and contributing to wise practice, Ocean Coast. Manage., 47, 273-298, 2004.

United Nations Environment Program: Conceptual Framework and Planning Guidelines for Integrated Coastal Area and River Basin Management, Split, Priority Actions Programme, 1999.

Van Buuren, M. W.: Knowledge for governance, governance of knowledge. Inclusive knowledge management in collaborative governance processes, Int. Public Manag. J., 12(2), 208-235, 2009.

Walters, C.: Challenges in adaptive management of riparian and coastal ecosystems, Conserv. Ecol., 1, 1, 1997.

Warner, J. and Van Buuren, M. W.: Multi-stakeholder Learning and Fighting on the River Scheldt, Int. Negotiation, 14, 417-439, 2009. 
Winterwerp, J. C. and Jeuken, M. C. J. L.: Samenvatting van het morfologisch onderzoek in het kader van de strategische milieueffectenrapportage en de Ontwikkelingsschets 2010, Arcadis Technum/WL Delft Hydraulics, 11 June, 2004.
Zanting, H. A. and ten Thij, F.: Langetermijnvisie Scheldeestuarium, Delft, Projectbureau LTV, 2001. 